\title{
Vulnerability Study of Public Buildings Subjected to Earthquake Event
}

\author{
Ismail Rozaina ${ }^{1,2,}$, Ibrahim Azmi ${ }^{2}$, and Razali Norhazlila ${ }^{2}$ \\ ${ }^{1}$ Institute for Infrastructure Engineering and Sustainable Management (IIESM), Universiti Teknologi \\ MARA, 40450 Shah Alam, Selangor, Malaysia \\ ${ }^{2}$ Faculty of Civil Engineering, Universiti Teknologi MARA, 40450 Shah Alam, Selangor, Malaysia
}

\begin{abstract}
The present article addresses on the earthquake study due to performance of critical frame reinforced concrete building. The buildings are analysed using Finite Element Modeling (FEM) under different types of analyses including Free Vibration Analysis (FVA), and Time History Analysis (THA) with varies earthquake intensities. The performances of the structure are shown by the yield point at beam-column connections where the internal forces at beam elements exceed the design capacity of the beams. The performance of critical frame reinforced concrete building when subjected to earthquake motion (Near source: Acheh) was addressed. The level of the damage state (Minor, Moderate, Major, Collapse level) has been defined as well. As a result, a greater damage index means that the members yield earlier and the plastic rotation is larger and vice versa. In general, there are no significant damage occurred to the structure. However, some non-structural elements of the building are expected to experience minor damages. These two buildings has no structural response to the earthquake because both Damage Index are less than 1.000. The study indicates that more than $50 \%$ of the buildings produced dynamic amplification factors of slightly more than one indicating not much of a dynamic response to the buildings.
\end{abstract}

\section{Introduction}

The reinforced concrete frame is easy to get affected due to this earthquake impact. Most of structural damages are results from inability of structural to perform surrounding soil and surface ruptures. It is essential to have a proper design detailing and selection of materials so that the reinforced concrete structure can withstand under severe combination of loadings such as dead load, imposed load, and earthquake loading. Malaysia is located at the low intensity of earthquake region. There are major tectonic plates around Malaysia. Engineers should concern and consider the earthquake impacts of buildings in Malaysian's building design procedure. According to $\mathrm{Li}$ [1], the reinforced concrete frame has to meet the requirements of performance-based earthquake engineering, since the influence of damage should be considered when conducting a structural performance assessment.

*Corresponding author: rozaina_fka_uitm@yahoo.com 
Moreno [2] present the performance of the building in low to moderate earthquake region. The results show that the buildings expected to have damages due to its poor expected performance and the seismic vulnerability study is very important to predict the damage of the buildings due to earthquake event. R, Ditommaso [3] estimated the fundamental period of reinforced concrete buildings and damage of structural and nonstructural element.

IDARC2D performs the nonlinear analysis. Barron [4] found that the flexible model results more displacement and interstorey drift than the rigid frame by get used of the IDARC 2-Dimensional software for reinforced concrete building [5]. The performance normally involves a qualitative process of measurement. Due to the reflection and expectation of the damage state, the values and parameters should be take place in order to measure quantitatively due to the performance level. Table 1 shows the ATC-13 damage level [6] in [7] to define the damage state level which adopted in this study. Table 2 shows the list of buildings analysed in this study.

Table 1. The Structural Engineers Association of California (SEAOC) damage levels [6].

\begin{tabular}{ccc}
\hline $\begin{array}{c}\text { SEAOC } \\
\text { Earthquake } \\
\text { Level }\end{array}$ & SEAOC Damage & ATC-13 Damage Factors (State) \\
\hline Minor & Without any damage & $\begin{array}{c}\text { D.F. } *=0 \text { (None) } \\
\text { D.F. }<0.01 \text { (Slight) }\end{array}$ \\
\hline \multirow{2}{*}{ Moderate } & $\begin{array}{c}\text { No structural damage, some } \\
\text { non-structural damage }\end{array}$ & $\begin{array}{c}0.01<\text { D.F. }<0.10 \text { (Light) } \\
0.01<\text { D.F. }<=0.30 \text { (Moderate) }\end{array}$ \\
\hline \multirow{2}{*}{ Major } & $\begin{array}{c}\text { No collapse, some structural } \\
\text { damage, non-structural } \\
\text { damage considerable }\end{array}$ & $\begin{array}{c}0.30<\text { D.F. }<=0.60 \text { (Heavy) } \\
0.60<\text { D.F. }<1.0 \text { (Major) }\end{array}$ \\
\hline Collapse & Collapse & D.F. $=1.0$ (Destroyed) \\
\hline
\end{tabular}

Table 2. List of buildings analysed.

\begin{tabular}{cccc}
\hline No. & Building Name & Story & Height (m) \\
\hline 1 & $\begin{array}{c}\text { Pejabat Daerah Kuala } \\
\text { Terengganu (PDKT) } \\
\text { Yayasan Negeri Sembilan } \\
\text { (YNS) }\end{array}$ & 5 & 19.20 \\
\hline
\end{tabular}

\section{Free vibration analysis}

Free vibration analysis is needed to understand the character of the structures for dynamic impact. According to Brebbia and Nardini [7], free vibration analysis, however, consists of finding only the natural frequencies and modes of the system. The natural periods and mode shapes are the most important factors to determine the dynamic characteristic. By identifying those parameters as well as the periods of the earthquakes, the dynamic characteristic can be specified. The factors are calculated by finding the ratio between the periods of earthquakes and the natural period of the structures. The formula for damping ratio $\xi$, frequency ratio $\beta$ and dynamic amplification factors $D[8]$ are shown as below.

$$
D=\frac{1}{\sqrt{1-\beta^{2}}+(2 \xi \beta)^{2}}
$$


where;

$\xi=\mathrm{C} / \mathrm{Cr}$, ( $\mathrm{C}$ is structure damping and $\mathrm{Cr}$ is critical damping.)

$\beta=\varpi / \omega$ (where $\varpi$ is the frequency of earthquake excitation and $\omega$ is the angular frequency of structure.

It shows that the resonance effect at beta $=1$. If $\mathrm{D}$ is equal to 1 the response of structure in dynamic is equivalent to the static response. However if $D$ is less than 1 , there is no structural response to the earthquake load.

Table 3 shows the dynamic characteristic parameter for the public buildings in Malaysia. For dynamic characteristic parameter we need to know the stories of the building, time period $\mathrm{T}$ which in second, frequency $\mathrm{f}$ in $\mathrm{Hz}$, and angular frequency $\omega$ in radian. All of these parameter we can get it from the SAP2000 software. Meanwhile, for dynamic amplification we can calculate the $\varpi, \beta$ and $D$ from all the value that we gained from the software. Pejabat Daerah Kuala Terengganu consists of 5 stories and the time period of the building is 12.2533 second, the frequency is $0.08161 \mathrm{~Hz}$ and the angular frequency is 0.5128 radian. Meanwhile, for Yayasan Negeri Sembilan consists of 13 stories and the time period of the building is 16.0942 second, the frequency is $0.06213 \mathrm{~Hz}$ and the angular frequency is 0.3903 radian. All of this value is gained from the SAP2000 software. After that, these values are going to be used to calculate the dynamic amplification.

Table 3. Dynamic characteristic parameter for the public buildings in Malaysia.

\begin{tabular}{ccccc}
\hline Building Name & Story & $\begin{array}{c}\text { Time } \\
\text { period, } \mathbf{T} \\
\text { (sec) }\end{array}$ & $\begin{array}{c}\text { Frequency, } \\
\boldsymbol{,} \boldsymbol{f}\end{array}$ & $\begin{array}{c}\text { Angular } \\
\text { Frequency, } \\
\boldsymbol{\omega}(\mathbf{r a d})\end{array}$ \\
\hline $\begin{array}{c}\text { Pejabat Daerah Kuala } \\
\text { Terengganu (PDKT) } \\
\text { Yayasan Negeri Sembilan } \\
\text { (YNS) }\end{array}$ & 5 & 12.2533 & 0.08161 & 0.5128 \\
\hline
\end{tabular}

Table 4. Dynamic amplification for buildings in Penisular Malaysia.

\begin{tabular}{cccccc}
\hline $\begin{array}{c}\text { Site Buildings To } \\
\text { Epicenter Acheh }\end{array}$ & $\mathbf{T}$ & $\varpi=\frac{2 \pi}{T}$ & $\omega$ & $\beta=\frac{\boldsymbol{w}}{\omega}$ & $\frac{1}{\sqrt{1-\beta^{2}}+(2 \xi \beta)^{2}}$ \\
\hline $\begin{array}{c}\text { Pejabat Daerah Kuala } \\
\text { Terengganu (PDKT) } \\
\text { Yayasan Negeri } \\
\text { Sembilan (YNS) }\end{array}$ & 3.02 & 2.08 & 0.51 & 4.08 & 0.064 \\
\hline
\end{tabular}

Table 4 shows the dynamic amplification for buildings in Peninsular Malaysia. For dynamic amplification parameter we need to know the epicenter of the earthquake, period $\mathrm{T}$ which in second, $\varpi, \omega, \beta$ and lastly the dynamic amplification, D. For Pejabat Daerah Kuala Terengganu the time taken, $\mathrm{T}$ is 3.02 second, $\sigma$ is 2.08 , angular frequency $\omega$ is $0.51, \beta$ is 4.08 and the dynamic amplification is 0.064 . Meanwhile, for Yayasan Negeri Sembilan the time taken, $\mathrm{T}$ is 2.36 second, $\omega$ is 2.66 , angular frequency $\omega$ is $0.39, \beta$ is 6.82 and the dynamic amplification is 0.022 . This dynamic amplification is calculated based on the formula that stated in the table below. The results show that the Pejabat Daerah Kuala Terengganu is having a factor of 0.064 due to Acheh earthquake. Whereas the Yayasan Negeri Sembilan is having a factor of 0.022 . 


\section{Dynamic non-linear analysis}

\subsection{Time history ground motion}

The present study the intensities as reported by MMD [8]. The Sumatra-Andaman (Acheh Earthquake) time history record is shown in Fig. 1 with 5000 number of outputs within 0.02 time steps with the maximum acceleration of $0.012 \mathrm{~g}$. The Acheh earthquake occurred in December 26, at Indian Ocean near to Acheh with magnitude 9.3 on the Richter scale. The acceleration is simulated to four variation of earthquake intensities; $0.05 \mathrm{~g}, 0.10 \mathrm{~g}, 0.15 \mathrm{~g}$, and $0.2 \mathrm{~g}$. This study used 5\% damped spectral acceleration as adopted in [9-13].

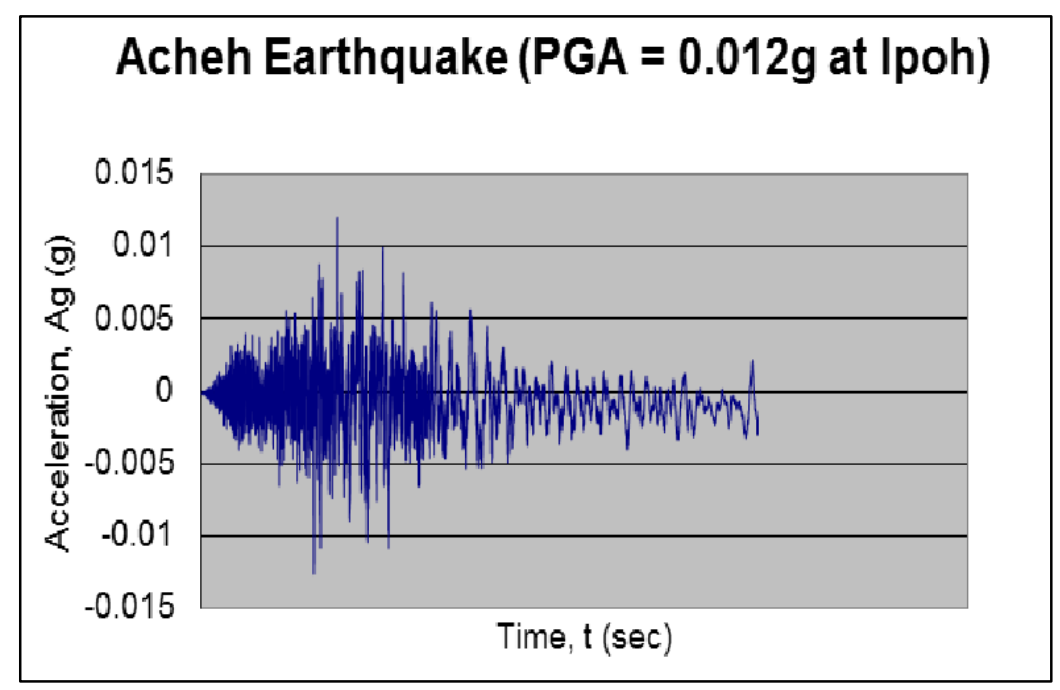

Fig. 1. Time history record of Acheh earthquake for peak ground acceleration 0.012g (December 26, 2004) [10-12].

\subsection{Modeling Concepts}

IDARC-2D was used to analyze non-linear dynamic to evaluate the vulnerability of the structures based on the damage indices. Fig. 2 outlines the modeling procedures. The modeling concepts applied are regular medium-rise structure and reinforced concrete with moment resisting frame. The dynamic non-linear analysis was performed using computer software IDARC 2D (Damage Analysis). British Standard [14] is referred to determine the loadings applied to the structure in the analysis steps to be applied as nodal loading in the modeling steps as shown in Fig. 4. FORTRAN based program developed by the University of Buffalo called IDARC2D was then used to carry out two dimensional analyses on selected frames from each building. This program is able to compute what is known as "structural damage index ${ }^{\text {ee }}$ which can be defined as a way of quantifying numerically the seismic damage suffered by buildings. Details of structural members such sizes of columns and beams, their steel reinforcements and the cumulative column axial loads are taken from the results that calculate by manual calculation and entered as input data in IDARC2D. Nodal weights were calculated and were based on tributary areas to the node and frame in question. The models were analyzed using the modified design response spectra. The computed damage indices were tabulated for easy reference and comparison [14-16]. 


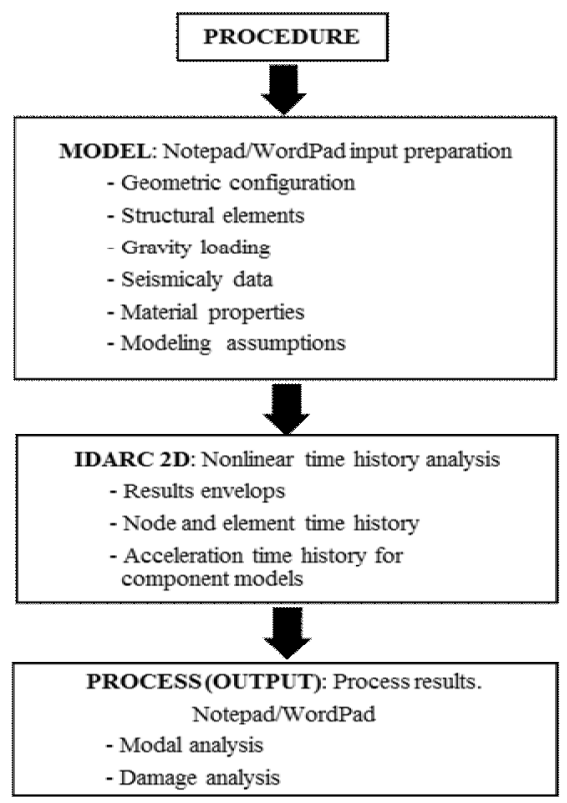

Fig. 2. Flowchart of modeling procedure.

\subsection{Plastic Hinge}

The term plastic hinge is used to describe the deformation of a section of a frame which consist of beams and columns where the plastic bending occurs. Normally, the plastic hinges for moment resisting frame type of buildings due to structural local failures occur either at beam or column connection. Fig. 3 shows the formation of the damage state location and plastic hinge of the moment resistance frame with four different intensities of ground acceleration. These represent the sequences of damage state of frames under earthquake loading. The study focus on damage level of the building and to know when the building starts yielding. Based on the result, for intensity $0.05 \mathrm{~g}$, the damage index is equal to zero and based on Damage Levels as stipulated in ATC-13 [6] the damage level at minor means free from damage. Table 5 and Table 6 show in detail the resultant of dynamic nonlinear analysis under various intensity; $0.05 \mathrm{~g}, 0.10 \mathrm{~g}, 0.15 \mathrm{~g}$, and $0.2 \mathrm{~g}$. These tables also show the location and time for each yielding point. All buildings has light damage level when the intensity $0.05 \mathrm{~g}$ applied to the model.

Table 5. Summarization of first yielding point and damage level for Pejabat Daerah Kuala Terengganu.

\begin{tabular}{cccccc}
\hline Intensity & Floor Level & Location & $\begin{array}{c}\text { Time } \\
(\mathbf{s e c})\end{array}$ & $\begin{array}{c}\text { Damage Index } \\
\text { (Overall) }\end{array}$ & Damage Level \\
\hline 0.012 & - & - & - & - & None \\
0.05 & 1 & Column & 2.29 & 0.044 & Minor slight \\
0.10 & 1 & Column & 2.18 & 1.000 & Collapse \\
0.15 & 1 & Column & 0.14 & 1.000 & Collapse \\
0.20 & 1 & Column & 0.11 & 1.000 & Collapse \\
\hline
\end{tabular}


Table 6. Summarization of first yielding point and damage level for Yayasan Negeri Sembilan.

\begin{tabular}{cccccc}
\hline Intensity & Floor Level & Location & $\begin{array}{c}\text { Time } \\
\text { (sec) }\end{array}$ & $\begin{array}{c}\text { Damage Index } \\
\text { (Overall) }\end{array}$ & Damage Level \\
\hline 0.012 & - & - & - & - & None \\
0.05 & 1 & Beam & 2.60 & 0.067 & Minor slight \\
0.10 & 1 & Beam & 2.58 & 0.142 & Moderate slight \\
0.15 & 1 & Beam & 0.69 & 0.168 & Moderate slight \\
0.20 & 1 & Beam & 0.52 & 1.000 & Moderate slight \\
\hline
\end{tabular}

In terms of damage pattern, the frame shows the locations of element structural where it started to yield, crack or collapse.

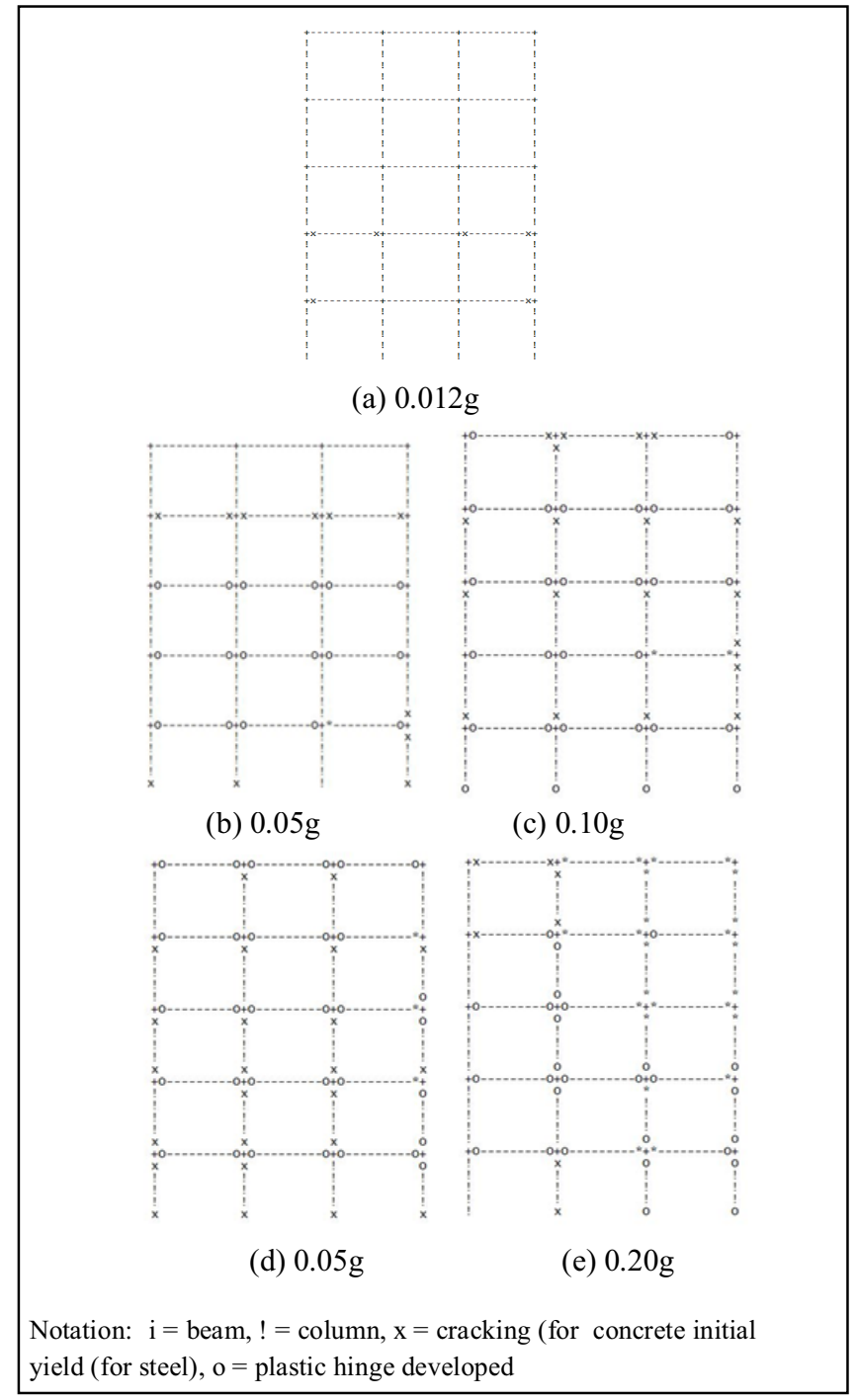

Fig. 3. Damage state frame under $0.012 \mathrm{~g}, 0.05 \mathrm{~g}, 0.10 \mathrm{~g}, 0.15 \mathrm{~g}$ and $0.20 \mathrm{~g}$ earthquake intensity for Pejabat Daerah Kuala Terengganu. 
From the results, the modal frame experienced cracking and yielding at the beam elements at the early stage. In Fig. 3, the ' $x$ ' symbol shows the occurrence of crack for concrete frame, the 'o' symbol shows the yield of plastic hinge has developed and the '*' symbol shows the local failure which exceed criteria. Based on Fig. 3, Pejabat Daerah Terenganu has experienced no damage at the early stage which $0.012 \mathrm{~g}$ intensity applied. For intensity 0.05 the damage pattern show the frame has started experienced yielding and cracking. For example the initial yield of the plastic hinge starts to develop at the beam in the first floor. Apart from the top floor, all beam ends act as plastic hinges, while only the columns show a few hinge behaviour. The beams act as hinges earlier than columns, nearly forming an overall symmetrical beam hinge system. The structure performance measured by the quantitative damage index is more reliable than displacement-based design.

\subsection{Performance level of the structure}

The program developed by Park [5] is used in this study to provide a measure of the accumulated damage index sustained by the components of the building included the maximum to ultimate deformations ratio. Table 7 shows in detail the summary of overall damage index of the buildings. The overall damage index for the building which can be referred to the SEAOC Damage Level in Table 1 and Table 8. The overall damage index for intensity $0.05 \mathrm{~g}$ categorized at minor level which no damage occurred for Block $\mathrm{K}$ and Police Quarters. Both building experienced no damage during $0.012 \mathrm{~g}$ intensity and experienced minor (light) level that means no structural damage, some non-structural damage. The reinforced concrete frames was completely collapse for Pejabat Daerah Kuala Terengganu for $0.20 \mathrm{~g}$ intensity and Yayasan Negeri Sembilan for $0.10 \mathrm{~g}$ intensity applied.

Table 7. Summarization of damage level.

\begin{tabular}{|c|c|c|c|c|c|c|c|}
\hline \multirow{2}{*}{ No. } & \multirow{2}{*}{$\begin{array}{l}\text { Building } \\
\text { name }\end{array}$} & \multirow[t]{2}{*}{$\begin{array}{l}\text { Type of } \\
\text { building }\end{array}$} & \multicolumn{5}{|c|}{$\begin{array}{l}\text { Overall Structural Damage } \\
\text { Index (g) }\end{array}$} \\
\hline & & & $\begin{array}{c}0.01 \\
2\end{array}$ & 0.05 & 0.10 & $\begin{array}{c}0.1 \\
5\end{array}$ & 0.20 \\
\hline 2. & $\begin{array}{l}\text { Pejabat } \\
\text { Daerah } \\
\text { Kuala } \\
\text { Terenggan } \\
\text { u }\end{array}$ & $\begin{array}{l}\text { Medium } \\
\text {-Rise }\end{array}$ & 0 & $\begin{array}{l}0.06 \\
7\end{array}$ & $\begin{array}{l}0.14 \\
2\end{array}$ & $\begin{array}{l}0.16 \\
8\end{array}$ & $\begin{array}{l}1.00 \\
0\end{array}$ \\
\hline 3. & $\begin{array}{l}\text { Yayasan } \\
\text { Negeri } \\
\text { Sembilan }\end{array}$ & $\begin{array}{l}\text { High- } \\
\text { Rise }\end{array}$ & 0 & $\begin{array}{l}0.04 \\
4\end{array}$ & $\begin{array}{l}1.00 \\
0\end{array}$ & $\begin{array}{l}1.00 \\
0\end{array}$ & $\begin{array}{l}1.00 \\
0\end{array}$ \\
\hline
\end{tabular}

Table 8. The contour damage level [6].

\begin{tabular}{lllll}
\hline $\begin{array}{c}\text { SEAOC } \\
\text { EQ Level }\end{array}$ & \multicolumn{1}{c}{ SEAOC Damage } & \multicolumn{2}{c}{ ATC-13 } \\
\hline \multirow{3}{*}{ Minor } & Without any Damage & None & $=0$ \\
& No Structural damage, & Light & $<$ & $\leq .01$ \\
& some non-structural & & $\leq 0.1$ \\
Moderate & damage & Moderate & $\leq 0.3$ \\
& No collapse, some & Heavy & $\leq$ & 0.6 \\
& structural damage, non- & & & \\
& structural damage & & & \\
Major & considerable & Major & $<1$ \\
Collapse & Collapse & Collapse & $=1$ \\
\hline
\end{tabular}




\section{Conclusions}

Most buildings that have been analysed subjected to the Acheh earthquake ground motion, have a damage indexes in the range of 0.0 to 1.000 . This low index that the buildings have only light or minor damage level. Local failures are mostly developed at beam connections followed by column connections. In general, there are no significant damage occurred to the structure. However some non-structural elements of the building are expected to experience minor damages. These two buildings has no structural response to the earthquake because both damage index are less than 1.000. From the overall analyses, it can be concluded that the high rise buildings in this study are affected by earthquake load more than the medium rise buildings.

The authors would like to acknowledge that this research has been carried out as part of a project FRGS with File No. 100-RMI/SF 16/6/2 (3/2015) funded by Ministry of Science, Technology and Innovation (MOSTI) and support from Universiti Teknologi MARA (UiTM).

\section{References}

[1] A. Adnan, T. L. Y. Patrick, R. Ismail, S.M. Shamsuddin, Artificial neural network application for predicting seismic damage index of buildings in Malaysia, Electronic J. of Structural Engineering, 12(1), 1-9, (2012)

[2] M. Mardiyono, R. Suryanita, A. Adnan, Intelligent monitoring system on prediction of building damage index using neural network, TELKOMNIKA Indonesian J. of Electrical Engineering, 10(1), 155-164, (2012)

[3] A. Adnan, H. Hendriyawan and M. Irsyam, The effect of the Latest Sumatra earthquake to Malaysian peninsular, J. Kejuruteraan Awam, 14(2), 12-25, (2002)

[4] T. Balendra and Z. Li, Seismic hazard in Singapore and Malaysia, Seismic hazard of Singapore and Malaysia, Electronic J. Structural Engineering, Special Issue (Earthquake engineering in the low and moderate seismic regions of Southeast Asia and Australia), 8, 57-63, (2008)

[5] M. F. Jamaludin, Performance of low rise building due to earthquake, Bachelor Degree Thesis, Universiti Teknologi MARA, Shah Alam, Malysia, (2011)

[6] M. Hassim, Analysis of medium rise building due to earthquake, Bachelor Degree Thesis, Universiti Teknologi MARA, Shah Alam, Malysia, (2011)

[7] C.A. Brebbia and D. Nardini, Dynamic analysis in solid mechanics by an alternative boundary element procedure, Int. J. of Soil Dynamics and Earthquake Engineering 2(4), 228-33 (1983)

[8] A.K. Chopra, and R.K. Goel, Capacity-demand-diagram methods for estimating seismic deformation of inelastic structures: SDF systems, Rep. No. PEER-1999/02, Pacific Earthquake (1999)

[9] M.S.H. Shamsudin, Performance of low rise concrete building under earthquake loadings, Bachelor Degree Thesis, Universiti Teknologi MARA, Shah Alam, Malysia (2010)

[10]R. Ismail, I. Azmi and A. Adnan, Application of artificial neural network in damage predeiction of buildings based on seismic zonation in Malaysia, Proc. of the $27^{\text {th }}$ Conference of Asean Federation of Engineering Organisations (Cafeo 27), Suntec City Convention Centre, Singapore, (2011).

[11]R. Ismail, I. Azmi and A. Adnan, Seismic damage analysis of reinforced concrete frame of public buildings in Ipoh subjected to Acheh Earthquake event, Proc. of The Int. Civil and Infrastructure Engineering Conf., Springer Singapore, 149 -157 (2015) 
[12]R. Ismail, The application of ANN in seismic evaluation of buildings, Master Thesis, Universiti Teknologi Malaysia, Shah Alam, Malysia, (2008)

[13]R. Ismail, I. Azmi and A. Adnan, Vulnerability of high-rise buildings in Kuala Lumpur subjected to Acheh earthquake event, Proc. of the Int. Civil and Infrastructure Engineering Conference, Springer Singapore, 139 -148 (2015)

[14] Y.J. Park, and A.M. Reinhorn, and S.K. Kunnath, , IDARC: Inelastic damage analysis of reinforced concrete frame shear wall structures, Technical Report: National Center for Earthquake Engineering Research, (1990)

[15] Anaxagoras Elenas, Intensity parameters as damage potential descriptors of earthquakes, III ECCOMAS Thematic Conf. on Computational Methods in Structural Dynamics and Earthquake Engineering, Corfu, Greece, (2011)

[16]R. Rajabi, M. Barghi, and R. Rajabi, Investigation of Park-Ang damage index model for flexural behavior of reinforced concrete columns, Structural Design of Tall \& Special Buildings, 22(17), pp. 1350-1358 (2013) 